\title{
Halsizlik ve Yorgunluğa Klinik Yaklaşım
}

The Clinical Approach of Asthenia and Fatigue Ahmet Çayakar

1 İç Hastalıkları Bölümü, Medical Park Hastanesi, Uşak/Türkiye

\section{özeT}

Halsizlik ve yorgunluk sübjektif olarak enerji azlığı, tükenme hissi ve güçsüzlük şeklinde tarif edilebilen özgül olmayan yakınmalardır. Aile hekimlerine yapılan başvurulardaki semptomların yaklaşık \%20'sini oluşturup zamanla aile yaşantısını, iş performansını ve sosyal ilişkileri olumsuz yönde etkilemektedir. Altı ayı geçen semptom kronik yorgunluk olarak kabul edilir. Toplumdaki oranı \%15 olarak hesaplanmış ve 30-50 yaş arasındaki sosyoekonomik şartları kötü, eğitim seviyesi düşük bayan grubunda daha sık gözlendiği bildirilmiştir. Zeminde organik rahatsızlıkları olanlarda ise saptanma oranı \%40’lara kadar yükselebilmektedir. Kronik yorgunluk sendromu olarak adlandırılan hastalık ise özellikle bayanları etkileyen ve kendine has kriterleri olan kompleks bir hadisedir. Kronik yorgunluk çeken her yedi hastadan biri bu sendroma dahil olup sıklığı üçüncü basamak sağlık kuruluşlarında \%10-15'e kadar çıkmaktadır. Kronik yorgunluğun etiyolojisinde en sık neden \%80 oranla psikolojik durumdaki değişikliklerdir. Diğer nedenler olarak kronik yorgunluk sendromu, romatolojik ve onkolojik hadiseler, enfeksiyonlar, nörolojik, hematolojik ve endokrinolojik hastalıklar ile son dönem organ hastalıkları sıralanmaktadır. Kronik yorgunluğa sıklıkla genel ağrı veya güçsüzlük semptomları da eşlik eder ve mevcut durum daha karmaşık hale gelebilir. Bu makalede pratik hayat için klinik yaklaşım sunulmaya çalışılmıştır.

Anahtar Kelimeler: halsizlik, yorgunluk, güçsüzlük, klinik yaklaşım

\section{ABSTRACT}

Fatigue or asthenia are nonspecific complaints that can be described as subjective lack of energy, feeling of exhaustion and weakness. It constitutes about $20 \%$ of the symptoms applied to the family physicians and affects family life, work performance and social relations negatively over time. The symptom lasting for six months is considered chronic fatigue. The ratio was calculated as $15 \%$ in the society and was reported that it has more frequently observed in poor female group with low education level at 30-50 years. Detection rates can be up to $40 \%$ if there is a accompanying medical discomfort. The disease called chronic fatigue syndrome on the other hand is a complex disease that affects women in particular and has its own criteria. One out of every seven patients suffering from chronic fatigue is involved in this syndrome and the incidence can be up to 10-15\% in tertiary health care facilities. Most frequent cause of the chronic fatigue etiology is the change in psychological status with the rates of 80\%. Other causes include chronic fatigue syndrome, rheumatologic and oncologic scenes, infections, neurological, hematological and endocrine diseases as well as end-stage organ diseases. Chronic fatigue is often accompanied by symptoms of general pain or weakness, and the present situation may become more complex. In this article, a clinical approach for practical life is tried to be presented..

Keywords: asthenia, fatigue, weakness, clinical approach

\section{Giriş}

Doğa dikkatli incelendiğinde halsizlik ve yorgunluğun, canlıların enerji depolarını daha etkin ve verimli kullanabilmek adına geliştirdikleri bir adaptasyon mekanizması olduğu gözlenecektir. İnsanlar da fizyolojik işleyişte sahip olduğu enerji düzeyi kritik alt sınıra ulaştığında bu hissi yaşayarak dinlenme ihtiyacı duyarlar. Yorgunluk normal koşullar altında aktivite sonrası hissedilir ve istirahatle geçer. Günün büyük bir kısmında belirginleşerek sübjektif enerji azlığı, tükenme hissi ya da güçsüzlük gibi özgül olmayan yakınmalarla tarif edildiği vakit ise hekimlerin karşısına klinik bir problem olarak çıkar.
Modern hayatın stresli yaşam koşulları, mevsim geçiş dönemleri, kalitesiz uyku ya da yetersiz dinlenme periyotları progresyonda özel öneme sahiptir. Doğal yorgunlukta kişi çalışmayla ilgili motivasyonunu korumakta, istirahat sonrası etkinliği gerçekleştirmek adına istekli ve hazır durumda olmaktadır. Güç ve enerji yokluğu anlamındaki 'Asthenos' sözcügü̈nden türetilmiş olan astenide ise bitkinlik dinlenmekle geçmez ve kişide isteksizlik hali daha ön plana çıkmıştır (1).

Yazışma Adresi/Address for Correspondence: Ahmet Çayakar, MD, iç Hastalıkları Kliniği, Özel Medical Park Hastanesi Uşak/Türkiye E-Posta/E-Mail: ahmetcayakar@hotmail.com || Tel: +90 5056487760 Received/Geliş Tarihi: 21 May 2019 || Accepted/Kabul Tarihi: 18 Eki 2019 Bu Eser Creative Commons Atıf-Gayriticari 4.0 Uluslararası Lisansı İle Lisanslanmıştır. This work is licensed under a Creative Commons Attribution-NonCommercial 4.0 International License (CC BY-NC 4.0). 


\section{Epidemiyoloji:}

Aile hekimlerine yapılan başvurular incelendiğinde bu semptomun yaklaşık \%20'lik payı aldığı ve aile yaşantısını, iş performansını ya da sosyal ilişkileri olumsuz yönde etkilediği gözlenmektedir (2). Sağlam kişilerde izole bir şekilde geçici olarak izlenebileceği gibi genelde çeşitli rahatsızıkların klinik belirtisi olarak karşımıza çıkmaktadır (3). Etiyolojisinin kabaca \%70 oranında belirlenebildiği söylenebilir. Avrupa'da 6000'e yakın kişiyle yapılan bir çalışmada; nedenler olarak en ön sıralarda depresyon, viral üst solunum yolu enfeksiyonu, anemi, akut bronşit, ilaç yan etkileri ve malignitenin yer aldığı anlaşıımıştır (4). Yorgunluk son bir ay içinde başlamış ise yeni, bu süreyi aşmış ise uzamış ve 6 aydan uzun sürmüş ise kronik olarak değerlendirilmektedir. Kronik yorgunluğun genel toplumdaki oranı \%15 olarak hesaplanmış olup bilhassa 3050 yaş arasındaki sosyoekonomik şartları kötü ve eğitim seviyesi düşük olan bayanlarda daha sık gözlendiği anlaşılmıştır (5). Kronikleşme oranı arttıkça ya da bilinen somatik rahatsızlık varlığında bu durumdan muzdarip kişilerin üçüncü basamak sağlık kuruluşlarına başvuru oranları artmaktadır (Şekil 1).

\section{Şekil 1. Klinikte yorgunluk sıklı̆̆}

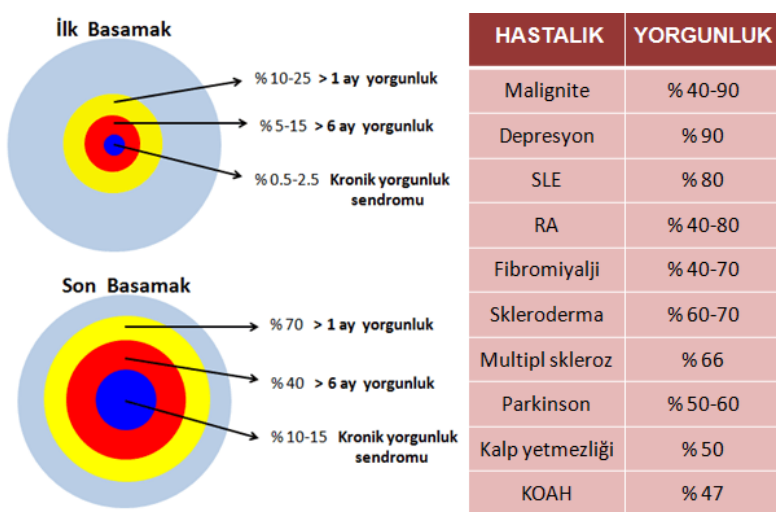

Nitekim 1985-90 yılları arasında Hollandalı aile hekimlerinin 260.000 hastayı incelendiği araştırmanın sonuçlarına göre; kronik hastalıklara sahip olanların kendilerini yorgun hissetme oranı \%40'lara kadar yükselmektedir (6). Kronik yorgunluk çekenlerin neredeyse üçte ikisi daha iyi prognozlu olan idiyopatik grup altında kalmakta ve daha sonra detaylıca bahsedilecek olan kronik yorgunluk sendromu (KYS) kriterlerini karşılamamaktadır. Teorik olarak kronik yorgunluğun aktivite azalmasıyla birlikte kardiyovasküler ölümler üzerinde olumsuz katkı sağlayacağı düşünülebilir. Ancak yapılan çalışmalarda tüm nedenlere bağlı ölüm oranları tahmin edilenden fazla bulunmamıştır. Negatif bir etki olarak sadece Amerika Birleşik Devletleri'nde yapılan bir çalışmanın analizinde intihara bağlı ölüm sıklığının normal popülasyona göre 8 kat arttığı belirtilmiştir (7).

\section{Patofizyoloji:}

Beynimizde kan-beyin bariyeri bulunmayan alanlara bakıldığında 3. ve 4. ventrikül çevresindeki orta hatta bir yoğunlaşma olduğu görülür. Bunlardan pineal bez, median eminens ve nörohipofiz sekretuvar özelliktedir ve nöron içermez. Subkommisural organ, area postrema ve lamina terminalisteki organum vaskülozum ise sensöryel yapıda olup özelleşmiş makrofaj kabul edilen microglialarla birlikte astrositleri bulundurur. İnterlökin (IL)-1 $\beta$, IL-6, Tümör nekrozis faktör (TNF) alfa ve interferon alfa gibi inflamatuvar sitokinler geniş yapıda düşük molekül ağırlıklı glikoproteinler oldukları için normalde kan-beyin bariyerinden pasif transport yoluyla geçemezler (8). Travma, enfeksiyon veya stres sonrası periferik inflamatuvar sinyallerin etkisiyle dolaşımda artmaya başlayan bu sitokinlerin, zamanla bariyer bulunmayan alanlara nüfuz ederek mikroglialardan prostaglandin E2 vasıtasıyla santral sitokin salınımına neden oldukları düşünülmektedir (9). Ayrıca, sitokinlerin serebral endoteldeki reseptörlere bağlanması sonrası nitrik oksitin aktive olarak santral sitokin hareketlenmesini hızlandırdığı hipotezi de mevcuttur. Sinyal yolu nükleer faktör (NF)-k $\beta$ üzerinden yürüyerek norepinefrin, dopamin ve serotonin gibi çeşitli yolaklardaki nörotransmitterlerde değişimi sağlamaktadır. Neticede zaman içinde ağrı, uyku bozukluğu ve yorgunluk gibi klinik sonuçların gün yüzüne çıktıkları düşünülmektedir (Resim 1).

Resim 1. Yorgunluk patofizyolojisi

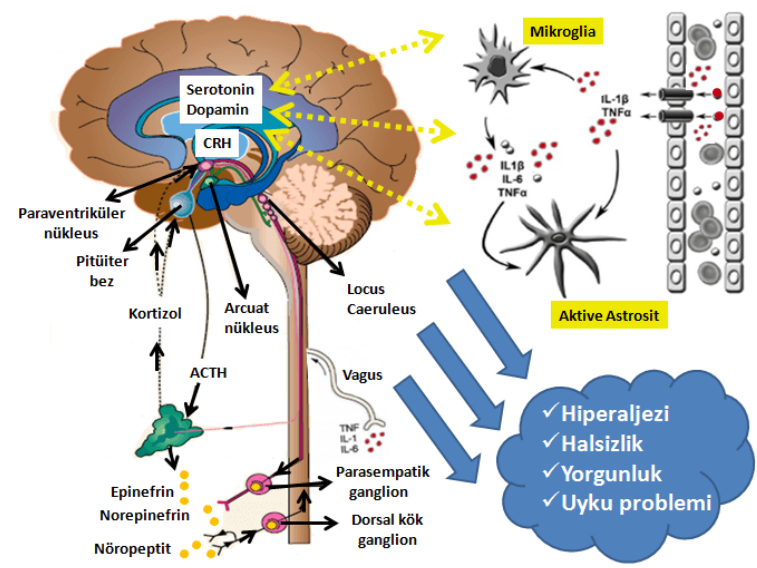


Gözlerimizi retiküler aktive edici sisteme çevirdiğimizde karmaşık ağ şeklinde oldukça düzensiz bir yapıyı gözleriz. Birçok nörotransmitter ile değişik işlevler sergileyen beyin sapındaki özel nöronlar liflerini medulla spinalis, pons, talamus ve hipotalamusa yollamaktadır. Ayrıca bu bölgede çok sayıda çekirdek kümelenmesi izlenmektedir. Bunlar orta hat boyunca yerleşen raphe çekirdekleri, lokus sereleus, ventral tegmental, interpedinküler ve merkezi çekirdeklerdir. Yoğun olarak serotonine sahip olan raphe çekirdekleri inhibitör etki gösterip uyku, dinlenme ve sakinlikle ilgilidir. Aksonları bazal gangliyonlar, talamus, hipotalamus, limbik sistem, beyin korteksi ve beyinciğe kadar ulaşmaktadır. Lokus sereleus noradrenalin, mezensefalon ise dopaminerjik nöronlar açısından zengin konumda olup sırasıyla enerji aktivitesi ve motor koordinasyonu düzenlerler. Yine aksonal bağlantıları bazal ganglion, limbik sistem ve özellikle frontal alan olmak üzere bütün beyin korteksine doğru uzanmaktadır. Kronik yorgunluğa sıklıkla uyku kalitesi, motivasyon, dikkat ve bellek işlevindeki bozuklukların eşlik etmesi düşünüldügünde patofizyolojide retiküler aktive edici sistemin de rol oynayabileceği kurgulanmıştır. Nitekim, bu hipotez doğrultusunda yürütülen bazı manyetik rezonans (MR) çalışmalarında ilgili bölgelerde özgül olmayan değişiklikler gözlenmiştir ancak bu durum sonrasında her hasta üzerinde saptanamamıştır (10).

Kolinerjik sistem nöronları yaygın olarak beyin sapına dağılmış vaziyette olup bellek, duyusal algılama, bilişsel işlev ve emosyonel durumun düzenlenmesinde baş roldedirler. Yapılan araştırmalar sonucunda, yorgunluk durumunda genelde sempatik sinir sistem aktivitesinde artış ve parasempatik aktivitede azalma olduğu gözlenmiştir (11). Otonom sinir sistemindeki değişiklikler neticesinde prefrontal ve anterior singulat korteksin nöral network aktivitesinin dengesizleştiği ve biyolojik saat, uyku ve enerji metabolizması üzerine etkiler oluşturduğu anlaşılmıştır. Ayrıca, birçok organın duyusal afferent bilgilerini taşıyan vagus sinirinin paragangliyonlarına IL-1 $\beta$ gelişiyle asetil kolin salınımının uyarıldığı belirtilmelidir. Oluşan impuls afferent fibrillerin bulunduğu nükleus traktus solitarius vasıtasıyla dorsal motor nükleusa iletilmektedir. Böylelikle beyinde proinflamatuvar sitokin üretimi ve salınımı tetiklenmiş olmaktadır. Nitekim deneysel çalışmalarda vagotomi sonrası değişik davranışsal etkilerin yok edilebildiği gösterilmiştir.
Sitokin etkilerini daha derinden değerlendirirsek, bunların sadece immün sistem hücreleri tarafından salgılanmadığı ayrıca endotel hücresi, adiposit, miyozit, depresyon döneminde astrositler, mikrogliya ve özellikle nöronlara yakın perivasküler mast hücrelerinden de sentezlenebildikleri söylenmelidir (12). Metabolizma çalışmalarında hiperinsülineminin TNF alfa ve hepatik Creaktif protein (CRP) düzeylerini yükselttiği ayrıca dolaşımdaki IL-6 seviyesinin neredeyse üçte birinin adipositler tarafından üretildiği belirlenmiştir (13). Özellikle bayanlarda uyku kaybında IL-6, TNF alfa ve CRP miktarında artış geliştiği gösterilmiştir. Yine, uyarılan hipotalamopituiter aks sonrası sağlanan kortizol artışı ve yağ dokusundaki düşük dereceli inflamasyonun, serotonin ve melatoninin prekürsörü olan triptofan miktarını azaltarak uyku kalitesini olumsuz yönde etkilediği anlaşılmıştır (14). IL-1 $\beta$ miktarı da hipotalamustaki paraventriküler nükleusta $\mathrm{CRH}$ aktivasyonu ile artış göstermektedir. Bu sitokin aktivitede azalma, hipersomni, iştahsızlık ve öğrenme güçlüğü gibi etkiler meydana getirip sosyal ilişkilerde içe kapanıklığı dahi tetikleyebilmektedir. Ayrıca, TNF alfanın beyinde IL-1 $\beta$ salgısını arttırarak prostaglandin üzerinden hiperaljezi mekanizmasını oluşturduğu düşünülmektedir. Belirtilen bu sitokin profili ve etkileri bizlere TNF alfa blokerleri, IL-1 reseptör antagonistleri ve IL-6 monoklonal antikoru olan Tosilizumab ile sağlanan yorgunluk hissindeki azalmayı açıklayabilmektedir. Interferon alfa uygulanmasının anhedoni, üzüntü hissi, yorgunluk, uykusuzluk ve ilgi kaybı gibi belirtiler oluşturması bilinen yan etkilerdir. Ruh halindeki bu değişikler, anterior singulat korteks, amigdala ve medial prefrontal korteksteki nöronlar arasındaki azalmış fonksiyonel bağlantı ile açıklanmıştır (15). Sitokinlerin uyku homeostazisi için de önemli olmasına sıçanlarda IL-1 $\beta^{\prime}$ nin santral enjeksiyonu sonrası NREM artışı sağlanması ve REM dönemindeki baskılanma örnek olarak verilebilir. Maligniteli hastalara baktığımızda, kemoterapi uygulanması sonrası IL-6, IL-10 ve TNF alfa miktarında artış meydana gelebileceği kolaylıkla tahmin edilebilir. Ancak, bu kişiler üzerinde yürütülen çalışmalarda kemoterapi ya da radyoterapi bitimine rağmen proinflamatuvar sitokinlerin halen yüksek olarak saptandığı ve \%30'luk grubun yıllarca sürebilen yorgunluk hissi yaşadığı görülmüştür. Bu durumun nedeni olarak inflamasyonla ilişkili genlerdeki polimorfizm ve transkripsiyon faktörü olan NF-k $\beta^{\prime}$ daki upregülasyon sorumlu tutulmuştur. 


\section{Kronik Yorgunluk Sendromu (KYS):}

Prevalansı \%0,5 olan ve en sık 20-50 yaş arası bayanları etkileyen kompleks bir hadisedir. Kronik yorgunluk çeken her 7 kişiden 1 tanesinde bulunur. Kronik yorgunluğu olanların üst basamak sağlık kuruluşlarına daha sık başvuru yapması tanı kriterlerinin değerlendirme şansı da yanında getirir. Bu nedenle üçüncü basamak sağlık kuruluşlarındaki sıklık oranı \%10-15'lere kadar yükselmektedir. Illk kez 1988 yılında Holmes ve arkadaşları; psikiyatrik rahatsızlıkların da dahil edildiği herhangi bir hastalığı bulunmayan kişilerde, ilaç yan etkisi söz konusu değilken 6 aydan daha uzun süren kalıcı ya da tekrarlayıcı vasıftaki halsizlikte bu sendromun söz konusu olabileceğini yayınladılar (16). Tanı için 11 kriterlerden en az 8 tanesi karşılanmalıdır. Ya da en az birer ay ara ile hekim tarafından saptanan ilk 3 kriterden en az 2'sini barındıran toplam 6 kriter sağlanmalıdır. Bunlar Tablo 1'de detaylı olarak listelenmiştir. 1994 yılında kriterlerde revizyona gidilmiş ve sensitivitesi daha da arttırılmıştır (17).

Tablo 1. Kronik Yorgunluk Sendromu

\begin{tabular}{|c|}
\hline - KRONIK YORGUNLUK SENDROMU - \\
\hline $\begin{array}{l}\text { - Kalıcı ya da tekrarlayıcı vasıfta } 6 \text { aydan uzun süren } \\
\text { halsizlik } \\
\text { 口 Psikiyatrik rahatsızlık dahil herhangi bir hastalık } \\
\text { bulunmamalı } \\
\text { 口 illaç yan etkisi söz konusu olmamalı } \\
\text { 口 Halsizlik ortalama günlük aktiviteleri } \% 50 \text { azaltmalı }\end{array}$ \\
\hline $\begin{array}{c}\text { Holmes Kriterleri } \\
\text { aşağıdaki kriterlerden en az } \underline{8 \text { tanesi ya da }} \\
\text { ilk üç kriterden en az ikisini barındıran } \underline{6 \text { tanesi }}\end{array}$ \\
\hline 1- Subfebril ateş veya titreme* \\
\hline 2- Farenjit veya boğaz ağrısı* \\
\hline 3- Ağrılı servikal veya aksiler lenfadenopati $(>2 \mathrm{~cm})^{*}$ \\
\hline 4- Egzersiz sonrası bir günden fazla halsizlik hissedilmesi \\
\hline 5- Açıklanamayan yaygın kas güçsüzlüğü \\
\hline 6- Miyalji \\
\hline 7- Gezici artralji (Kızarıklık ya da şişlik olmamalı) \\
\hline 8- Yaygın baş ağrısı \\
\hline $\begin{array}{l}\text { 9- Nöropsikiyatrik şikayetler (Fotofobi, geçici görsel skotomlar, } \\
\text { artmış irritabilite, konfüzyon, düşünce tembelliği, konsantrasyon } \\
\text { zorluğu) }\end{array}$ \\
\hline 10- Uyku bozukluğu (Hipersomni ya da insomnia) \\
\hline $\begin{array}{l}\text { 11- Semptomların birkaç saat ya da gün içinde ortaya } \\
\text { çıkması }\end{array}$ \\
\hline $\begin{array}{l}\text { *: En az birer ay ara ile iki defa hekim tarafından } \\
\text { saptanmalıdır }\end{array}$ \\
\hline $\begin{array}{c}\text { Fukuda Kriterleri } \\
\text { Ateş yüksekliği ve kas güçsüzlüğü çıkarılmıştır. } \\
4 \text { kriterin pozitif olması şartı aranır. }\end{array}$ \\
\hline
\end{tabular}

Ergenlerde KYS daha büyük karma bir okula başlamanın getirdiği sosyal beklentilerdeki değişim ve Epstein-Barr virüs (EBV)'ye maruziyetteki artış nedeniyle ilkokuldan ortaokula geçiş döneminde daha sık olarak gözlenir. Bu grupta uygulanan mevcut kriterlere ek olarak iştahsızlık, zayıflama, karın ağrısı, bulantı, bulanık görme ve okul performansında düşme gibi semptomların da gözlenebileceği bilinmelidir. Bu durumdaki çoğu ergende 2-3 yıl gibi bir sürede iyileşme sağlanabileceği bildirilmektedir (18). Patofizyolojide öne sürülen teoriler arasında ilk olarak EBV, insan T lenfosit virüs (HTLV), hepatit $C$, enterovirüs ve retrovirüs enfeksiyonları öngörülmüştür ancak bunlar net olarak kanıtlanamamıştır. Nitekim, ampirik olarak tatbik edilen asiklovir ya da interferon tedavilerinden de fayda sağlanamamıştır. Diğer olası açıklamalar; aslında bir psikiyatrik bozukluk ya da beyin sapı nöroendokrin cevaplarındaki gerçekleşen değişimin yansıması olabileceği yönündedir. Yapılan bazı MR çalışmalarında hastalarda subkortikal anormallikler saptanmıştır. Buradan hareketle çeşitli nörofizyolojik çalışmalar düzenlenmiş ancak tutarlı bir sonuca ulaşılamamıştır. Son yapılan araştırmalarda KYS'li kişilerde serotonerjik sistemde upregülasyon ve \%30 oranında hiperkortizolizm saptandığı bildirilmiştir. Ayrıca interferon alfa, IL-1 $\beta$, IL-6 ve TNF alfa düzeylerinde artış da saptanmıştır. KYS'de uykuya dalmada güçlük, uykuda kesilme ve gün içinde uyuklama daha fazla bildirilmektedir. Bu gözlem, sorumlu etken acaba uyku düzenindeki bir bozukluk olabilir mi sorusunu gündeme getirmiş ancak polisomnografi çalışmaları ile yine net bir cevap ortaya konulamamıştır. Genelde hastalar anamnezde sıklıkla mükemmel bir fiziksel zindelikte ve enerji dolu olduklarını ancak sonradan ani bir başlangıç olduğunu ifade ederler. Birçoğu aynı zamanda iştahsızlık, bulantı, aşırı gece terlemesi, baş dönmesi gibi semptomları da dile getirebilir. Ayrıca bu tip kişilerde alkol ve santral sinir sistemini etkileyen ilaçlara karşı intolerans da gözlenebilmektedir. Zamanla hastaların üçte biri sosyal ilişkilerinde gerileme yaşayarak çalışamayacak duruma düşebilir. Fibromiyalji ve irritabl bağırsak sendromunun sıklıkla eşlik etmesi de şaşırtıcı gelmemelidir. Toplum içindeki somatizasyon, mizaç, panik bozukluk, anksiyete ve depresyon oranları sırasıyla $\% 0,03-1,2-3,5-5$ ve 10 iken, bu oranlar KYS'de artış göstererek \%25 - 25 - 20 - 20 ve 60'lı değerlere kadar yükselebilmektedir. KYS'nin atipik bir depresyon çeşidi olabileceği yönündeki görüşler hastaların depresyonla 
karışabilecek benzer semptomlara ek olarak boğaz ağrısı, lenfadenopati ve artralji yaşaması, depresyonda gözlenen hipotalamo-pitüiter aks upregülasyonu yerine down regülasyon geliştiğinin gösterilmesi ve antidepresanlarla elde edilen kötü yanıt ile geri plana itilmiştir.

\section{Halsizlik ve Yorgunluk nedenleri:}

İlk yapılması gereken bu durumu açıklayabilecek organik bir nedenin var olup olmadığının araştırılmasıdır. Ayırıcı tanı çok geniştir. En sık neden yaklaşık \%80 oranla psikolojik durumdaki değişikliklerdir. Diğer sebepler olarak KYS, romatolojik hadiseler, maligniteler, son dönem organ hastalıkları ve enfeksiyon tabloları sıralanabilir (19). Kilo alımı, nöropati gelişimi, glukoz seviyesinde değişkenlik, hipoglisemi ve emosyonel labilitenin yaşanabildiği diyabetes mellitus, metabolizmayı direkt düzenleyen hipotiroidi ya da hipertiroidi, hipopitüitarizm, sürrenal yetmezlik, hipogonadizm ve hiperparatiroidi gibi endokrinolojik hastalıklar önemlidir. Hematolojik problemler ile hipopotasemi, hipokalsemi, hipomagnezemi, hiponatremi gibi iyon dengesizlikleri hekimlerinin zorlanmadan değerlendirmesi gereken konulardır. Halsizlik ve yorgunluk yapan diğer nedenler olarak nörolojik hastalıklardan parkinson, amiyotrofik lateral skleroz, demans, multipl skleroz, miyasteniya gravis, nöromüsküler hastalıklar ve özellikle böbrek ya da karaciğer yetmezliğinde kullanılan sedatif, antikolinerjik, digoksin ve antiepileptik gibi ilaçların etkileri sayılabilir (Tablo 2). Tanı koyma sürecinde atlanılmaması için azami dikkat gerektiren ve gizli tehlike olarak kabul edebileceğimiz hastalıklar: Malignite, maskeli depresyon, glüten enteropatisi, gıda intoleransı, tüberküloz, bruselloz, hepatitler, bağ dokusu hastalıkları, kardiyomiyopati, yeni başlayan kalp yetmezliği, hasta sinüs sendromu, hipomagnezemi, hemokromatozis, hiperparatirodizm, adrenal yetmezlik, cushing sendromu, ağır metal zehirlenmesi, alkol yoksunluk sendromu, spinal disfonksiyon, multipl skleroz ve miyasteniya gravis olarak sıralanabilir.

\section{Yorgunluk + Vücut Ağrısı:}

Jeneralize kas ve eklem ağrısı, polimiyaljiya romatika, romatoid artrit, sistemik lupus eritematozus, polimiyozit ve vaskülit gibi inflamatuvar ya da fibromiyalji, jeneralize osteoartrit ve miyofasiyal ağrı sendromu gibi çeşitli rahatsızlıklarda izlenebilir. Inaktivasyon sonrası eklem hareketlerinde duyulan rahatsızlık hissi şeklinde tarif edebileceğimiz tutukluk, non-inflamatuvar nedenlerde genelde sabahları yarım saatten az sürmektedir. Romatolojik olaylarda ise bu semptomdan daha uzun süreli yakınılır (20). Ayrıca depresyon, KYS, viral enfeksiyonlar, bruselloz, sepsis, hipotiroidi, hipoparatiroidi, osteomalazi ve Paget hastalığı gibi metabolik hastalıklar, parkinsonizm, lösemi, lenfoma, multipl miyelom, yaygın metastaz ve paraneoplastik sendromlarda da yaygın vücut ağrısının bulunabileceği bilinmelidir. Kronik yaygın ağrının en sık sebebini genel dahiliye polikliniğindeki sıklığı kabaca \%5 olarak tahmin edilen fibromiyalji oluşturur. Zemininde santral sensitizasyona bağlı değişmiş bir ağrı algılaması bulunmakta olup hastalar hafif basınca karşı artmış hassasiyet, yorgunluk hissi ve kötü uyku kalitesi tarif ederler. Ağrı genelde sabah sertliğinin de eşlik edebildiği aralıksız karakterdedir ve egzersizle rahatlama sağlanamaz. Ayrıca, bu tip hastalar çeşitli tipte parestezi ya da objektif sinovit kanıtının izlenemediği el ve ayak şişliklerinden yakınırlar. Sıklıkla dinlenememe hali ve kronik yorgunluk sendromu bu tabloya eşlik edebilmektedir (21). Ağrıdan yakınan bir kişide romatizmal hadiseye bağlı eklem hasarı da başlamış ise tabloya sekonder kas güçsüzlüğü de eklenecektir. Zamanla hasarlı eklemin işini yapmak adına daha çok enerji harcanması, hareketsizlik sonrası kondisyondaki azalma ve bahçe işleriyle uğraşma örneğinde olduğu gibi stres giderici hobilerin yapılamaması kronik yorgunluğa doğru giden yolu uygun hale getirecektir.

\section{Yorgunluk + Güçsüzlük:}

Hastalar güçsüzlüğü tarif ederken dispne, artralji, genel yorgunluk veya hareket kısıtıı ı̆̆ ile karıştırabilmektedir. Bu yüzden ne kastedildiğini iyi anlamalıyız. Objektif olarak güçsüzlük kanıtı var mı? Jeneralize mi yoksa lokal mi? Akşamları mı daha fazla oluyor? Alkol tüketim hikayesi nasıl? Kullandığı ilaçlar nelerdir? Kronik yorgunlukta güçsüzlük hissi çoğunlukla gerçek bir kas hasarı olmadan gözlenir ve çoğu hastada objektif kas güçsüzlüğü kanıtı bulunamaz. Genelde kendini sınırlayıcı veya tekrarlayıcı vasıfta olup vital bulgular ve laboratuvar değerleri normal sınırlardadır. Böyle bir durumda anksiyete veya depresyonun eşlik etmesi daha olasıdır. Miyopatik tabloda ise semptomlar genelde progresif seyirlidir, genel bir güçsüzlük hali vardır ve anormal vital bulgular saptanır. Sıklıkla sistemik semptomlar eşlik etmektedir. Kreatin kinaz 
(CK) yükselmesi önemlidir. Aile öyküsü ise özellikle paralizi, inklüzyon cisimcikli miyozit ya da endokrin müsküler distrofiler, hiper ya da hipokalemik periyodik

Tablo 2. Halsizlik ve yorgunluk nedenleri

\begin{tabular}{|c|c|c|c|}
\hline FizYOLOJik & $\begin{array}{l}\text { - Stres } \\
\text { - Yetersiz beslenme } \\
\text { - Uyku bozukluğu }\end{array}$ & $\begin{array}{l}\text { - Aşırı sıcak ortam } \\
\text { - Sedanter yaşam } \\
\text { - Dehidratasyon }\end{array}$ & $\begin{array}{l}\text { - Yetersiz dinlenme } \\
\text { - Kronik ağrı }\end{array}$ \\
\hline PsikOLOJik & $\begin{array}{l}\text { - Depresyon } \\
\text { - Posttravmatik stres } \\
\text { - Anoreksiya nervoza } \\
\text { - Okul fobisi }\end{array}$ & $\begin{array}{l}\text { - Anksiyete } \\
\text { - Bipolar bozukluk } \\
\text { - Şizofreni } \\
\text { - Sekonder kazanç }\end{array}$ & $\begin{array}{l}\text { - Somatizasyon } \\
\text { - Bağılmlı kişilik } \\
\text { - Seksüel disfonksiyon } \\
\text { - Kötüye kullanılma }\end{array}$ \\
\hline \multirow{8}{*}{$\begin{array}{c}\text { SISTEMIK } \\
\text { HASTALIKLAR }\end{array}$} & $\begin{array}{l}\text { - Diabetes mellütüs } \\
\text { - Hiperparatiroidi } \\
\text { - Hipopitüitarizm } \\
\end{array}$ & $\begin{array}{l}\text { - Hipotiroidizm } \\
\text { - Adrenal yetmezlik } \\
\text { - Osteomalazi } \\
\end{array}$ & $\begin{array}{l}\text { - Hipertiroidi } \\
\text { - Cushing sendromu } \\
\text { - Obesite }\end{array}$ \\
\hline & $\begin{array}{l}\text { - Romatoid artrit } \\
\text { - Sjögren } \\
\text { - Sarkoidoz } \\
\end{array}$ & $\begin{array}{l}\text { - SLE } \\
\text { - Miyozit } \\
\text { - Fibromiyalji } \\
\end{array}$ & $\begin{array}{l}\text { - MCTD } \\
\text { - DHA } \\
\text { - PMR } \\
\end{array}$ \\
\hline & $\begin{array}{l}\text { - Anemi } \\
\text { - Lenfoma }\end{array}$ & $\begin{array}{l}\text { - Demir eksikliği } \\
\text { - Lösemi }\end{array}$ & - Vitamin B12 eksikliği \\
\hline & $\begin{array}{l}\text { - Böbrek yetmezliği } \\
\text { - Hiponatremi } \\
\text { - Hipokalsemi }\end{array}$ & $\begin{array}{l}\text { - Hipokalemi } \\
\text { - Hiperkalsemi }\end{array}$ & $\begin{array}{l}\text { - Hiperkalemi } \\
\text { - Hipomagnezemi }\end{array}$ \\
\hline & $\begin{array}{l}\text { - Hepatit } \\
\text { - IBH }\end{array}$ & - Siroz & - Çölyak \\
\hline & $\begin{array}{l}\text { - Kalp yetmezliği } \\
\text { - KAH }\end{array}$ & - Kalp kapak hastalıkları & - Kardiyomiyopati \\
\hline & $\begin{array}{l}\mathrm{KOAH} \\
\text { - IAH } \\
\end{array}$ & - Astım & - OSAS \\
\hline & $\begin{array}{l}\text { - Stroke } \\
\text { - Myastenia gravis } \\
\text { - Poliomyelit } \\
\text { - Botulizm } \\
\end{array}$ & $\begin{array}{l}\text { - Beyin malignitesi } \\
\text { - ALS } \\
\text { - Disk herniasyonu } \\
\text { - Demans }\end{array}$ & $\begin{array}{l}\text { - Multipl skleroz } \\
\text { - Musküler distrofi } \\
\text { - GBS } \\
\text { - Parkinson } \\
\end{array}$ \\
\hline ENFEKSIYON & $\begin{array}{l}\text { - Tüberküloz } \\
\text { - Brusella } \\
\text { - CMV } \\
\text { - Toksoplazma } \\
\end{array}$ & $\begin{array}{l}\text { - Lyme } \\
\text { - Hepatit B/C } \\
\text { - Influenza } \\
\text { - Parazit } \\
\end{array}$ & $\begin{array}{l}\text { - Endokardit } \\
\text { - EBV } \\
\text { - Q ateşi }\end{array}$ \\
\hline MALIGNITE & - Solid tümör & - Paraneoplastik & \\
\hline İLAÇLAR & $\begin{array}{l}\text { - Hipnotik } \\
\text { - Sedatif } \\
\text { - Amitriptilin } \\
\text { - Beta bloker } \\
\text { - Antihistaminik } \\
\text { - Kolşisin } \\
\text { - Statin } \\
\text { - Kemoterapotik } \\
\end{array}$ & $\begin{array}{l}\text { - Antidepresan } \\
\text { - Amfetamin } \\
\text { - Interferon } \\
\text { - Metildopa } \\
\text { - Antiretroviral } \\
\text { - Steroid } \\
\text { - GNRH analoğu } \\
\text { - İlaçlar arası etkileşim } \\
\end{array}$ & $\begin{array}{l}\text { - Trazodone } \\
\text { - Opioid } \\
\text { - Antihipertansif } \\
\text { - Amiadorone } \\
\text { - Propiltiourasil } \\
\text { - Fibrat } \\
\text { - Kas gevşetici } \\
\text { - Illaç kötüye kullanımı }\end{array}$ \\
\hline DiĞER & $\begin{array}{l}\text { - Malnutrisyon } \\
\text { - Gebelik } \\
\text { - Alkolizm } \\
\text { - Organik solvent }\end{array}$ & $\begin{array}{l}\text { - GÖRS } \\
\text { - Post partum } \\
\text { - Ağır metal intoksikasyonu } \\
\text { - Karbonmonoksit }\end{array}$ & $\begin{array}{l}\text { - Allerjik rinit } \\
\text { - Post-op dönem } \\
\text { - Organofosfat }\end{array}$ \\
\hline
\end{tabular}

SLE: Sistemik Lupus Eritematozis, MCTD: Mikst Konnektif Doku Hastalığı, DHA: Dev hücreli arterit, PMR: Polimiyaliya Romatika, iBH: inflamatuar Bağırsak Hastalı̆̆ı, KAH: Koroner Arter Hastalığı, KOAH: Kronik Obstrüktif Akciğer Hastalı̆̆ı, OSAS: Obstrüktif Sleep Apne Sendromu, IAH: intersitisyel Akciğer Hastalığı, ALS: Amyotrofik Lateral Skleroz, GBS: Guillian Barre sendromu, EBV: Epstein-Barr virüs, CMV: Sitomegalovirüs, GÖRS: Gastroözofagial Reflü Sendromu

Güçsüzlük yapan hastalıkları kabaca enfeksiyöz, endokrinolojik, romatolojik, metabolik, nörolojik, toksik ve distrofi gruplarına ayrılabiliriz. Akut başlangıçta enfeksiyon ya da inme, subakut başlangıçta ise ilaç yan etkileri, elektrolit bozukluğu ve romatolojik hastalıklar ilk planda akla getirilmelidir. Kronik progresif gidiş genetik ve metabolik miyopatilere has özelliklerdir. Jeneralize güçsüzlük polimiyaljiya romatika, miyozitler, paraneoplastik sendrom ve steroid tedavisinin ani bırakılması ile lokalize güçsüzlük ise serebral metastaz, serebrovasküler hastalık veya radikülopatilerde gözlenebilir. Proksimal kas güçsüzlüğü romatizmal hastalıklara özgü iken distal kas gruplarındaki güçsüzlük inklüzyon cisimcikli miyozit, distrofiler, piramidal traktus hasarı ya da periferal nöropati 
sonucu gelişebilir. Artralji, halsizlik, miyalji ve solunum semptomları varlığında anamnezde 1-2 hafta önce ateş, üst solunum yollarına ya da gastrointestinal sisteme ait şikayetlerin gözlendiği prodromal semptomlar tarif ediliyor ise viral miyozit akla getirilmelidir. Bu tabloda miyopati multifokal olup bilateral büyük kas gruplarını etkiler ve genellikle şişlik eşlik eder. Ek olarak raş; meningeal belirtiler, kalp ve diyafram tutulumu sonrası aritmi, anjina pektoris, solunum yetmezliği ve nadiren rabdomiyoliz gözlenebilir. Subklinik hipotiroidizmde kas şikayetlerinin tek semptom olarak karşımıza çıkabileceği bilinmelidir. Kronik böbrek yetmezliği bulunan bir kişide özellikle alt ekstremite proksimal kas güçsüzlüğü bulunduğunda paratiroid hastalığından şüphelenilmelidir. Osteomalazide de hastalar tarafından halsizlik, yorgunluk, kemik ağrıları, proksimal kas güçsüzlüğü ve kramp gibi şikayetler aktarılmaktadır. Burada kemik matriks mineralizasyonunda bozulma ve adeta yumuşama mevcuttur. Ağrının ortaya çıkışı muhtemelen osteoid dokudaki hidrasyon artışı sonucu periost gerilimi yaşanması ve kemiğe baskı gelişmesi ile ilgilidir. Hipokalsemi, hipofosfatemi, alkalen fosfataz artışı ve paratiroid hormon artışı izlenebilir. Cushing sendromu açısından kilo alımı ve proksimal kas güçsüzlüğü, adrenal yetmezlik açısından halsizlik, yorgunluk ve ciltte koyulaşma, ortostatik hipotansiyon uyarıcı olabilir. Ayrıca elektrolit bozukluklarından sodyum, potasyum ve kalsiyum yükseklikleri ile magnezyum ve fosfor düşüklüklerinde yorgunluk, kas güçsüzlüğü hatta ağrı yaşanabilmektedir. Romatolojik olarak akıllara ilk gelen hastalıklar dermatomiyozit, polimiyozit ve inklüzyon cisimcikli miyozit olmalıdır. Tipik hasta profili ilk ikisi için 20-50 yaş arası bir bayan, inklüzyon cisimcikli miyozit için 50 yaş üstü erkektir. Ağrıdan ziyade subakut ya da kronik simetrik proksimal güçsüzlük ön plandadır. Enfeksiyon tablolarına göre daha ağrısız bir gidiş söz konusudur. Ateş yüksekliği, raş, kilo kaybı, nefes darlığı ve alt özofagus sfinkter disfonksiyonu sonucu göğüste yanma hissi ve disfaji gelişebilir. CRP ve sedimantasyon değerinde yükselme, \%90 oranında CK artışı ve $\% 80$ oranında antinükleer antikor (ANA) pozitifliği beklenmektedir (22). Glikogenez basamakları, yağ asit oksidasyonu ve mitokondriyal etkilenme sonucu kas dokusunda yeterli enerji üretilememesi neticesi metabolik miyopatiler gelişir. Çocukluk çağındaki güçsüzlük başlangıcı Duchenne müsküler distrofi için anlamlıdır. Erişkin çağda başlayabilen ve polimiyozit ile karışabilen non-inflamatuvar miyopatiler olarak miyofosforilaz eksikliği, karnitin palmitil transferaz 2 eksikliği, mitokondriyal miyopati, disferlinopati, fasiyoskapulohumeral müsküler distrofi ve proksimal miyotonik distrofi tip 2 sayılabilmelidir (23). Nörolojik açıdan ani başlangıç ve nöroanatomik dağılıma uyan güçsüzlük serebrovasküler hastalık ya da spinal kord zedelenmesini ilk planda çağrıştırır. Progresif seyir metastazı, periyodik seyir ve ataklar ise periyodik paraliziyi simgeler. Pitozis, yüz kaslarında güçsüzlük, eforla şikayetlerde artış görülüp istirahatte azalması ve kolay yorulmadan şikayetçi olma miyasteniya gravis için tipiktir. Değişik alanların multipl nörolojik defisitleri gözlendiğinde multipl skleroz düşünülmelidir. Akciğer malign neoplazmı, lenfoma ya da timoma tanısına sahip hastalarda paraneoplastik olarak Lambert Eaton sendromu gelişebilme olasılı̆̆ı açısından uyanık olmak gerekir. Bu sendrom küçük hücreli akciğer kanserlerinin \%2'sinde hiporefleksi ile birlikte izlenir. Nörolojide santral genel patoloji ve diffüz güçsüzlükte amiyotrofik lateral skleroz, santral fokal patoloji ve diffüz güçsüzlükte stroke ya da multipl skleroz, periferik patoloji ve diffüz güçsüzlükte Guillain Barre sendromu ve polinöropati, periferik ve lokal güçsüzlükte ise radikülopatiler ve periferal nöropati düşünülmesi işimizi kolaylaştıracaktır (24). Toksik miyopatilerde ise en suçlu ajan statinlerdir. Bu ajanda miyalji sıklığı \%6, özellikle fibratla kombine kullanımda rastlanan rabdomiyoliz sıklı̆̆ ise 4/100.000 olarak hesaplanmıştır. Semptomlar ilaç alımından haftalar ya da aylar sonra başlar ve bırakıldıktan sonraki 4-8 hafta içinde geriler. CK'da 10 kat üzeri artışlar gözlenebilen bu tabloda 50 yaş üstü olmak, polifarmasi, böbrek ve karaciğerin fonksiyon kapasitesindeki azalma risk faktörleridir. Kortikosteroidler de özellikle 30 mg/gün gibi dozlarda 4 haftadan fazla süreyle kullanıldı̆̆ında emosyonel labilitenin de eşlik edebildiği ağrısız kas güçsüzlüğü yapmaktadır. Bu tablo ileri yaştaki kanser hastalarında daha fazla izlenir ve CK normal olarak saptanır. Amiadoron; distal sensörimotor nöropati, proksimal ve distal kas güçsüzlügü açısından sabıkalı bir ilaçtır. Özellikle böbrek hastalığı olan bir kişide statin ile birlikte kullanımında bu yan etkilerin ortaya çıkma olasıllığı artacaktır. Kolşisin ile ilgili olarak bilhassa 50 yaş üstü böbrek hastalarının kronik kullanımında yavaş başlangıçlı, ağrısız, progresif proksimal kas güçsüzlüğü gelişebileceği ve CK düzeylerinde hafif artışlar izlenebileceği bilinmelidir (25). Genel öneri olarak bu tip hastalarda kreatinin klerensi $50 \mathrm{ml} / \mathrm{dk}$. altına inince ilaç 
dozu yarıya düşürülmelidir. Antiretroviral ajan olarak kullanılan zidovudin ile de minimal CK artışıyla birlikte sinsi ve progresif kas güçsüzlüğü ya da miyalji gelişebilmektedir. Ayrıca klozapin, vinkristin, akne tedavisinde kullanılan isoretinoik asit, epsilon aminokaproik asit, siklosporin ve alkol tüketiminin de miyopati yapabileceği bilinmelidir.

\section{Klinik Değerlendirme:}

Halsizlik ve yorgunluktan yakınan hastalara psikolojik değerlendirme yapıldığında birçok kişide gizlenme eğilimindeki psikolojik yakınmaların eşliği görülecektir. Bunlar; dikkat ya da bellek problemleri, huzursuzluk, tahammülsüzlük, kolay sinirlenme, uyku bozukluğu, motivasyonsuzluk ve cinsel işlev bozukluğu gibi belirtilerdir. Ayrıca baş dönmesi, sersemlik hissi, jeneralize ya da lokalize vücut ağrısı, tutukluk, subfebril ateşlenme gibi somatik şikayetler de dile getirilebilir. Yorgunluk başlangıcı nasıl oldu, gün içindeki seyri, iş yapmaya etkisi, istirahatle ve olaylarla olan ilişkisi ne durumda diye sorgulamalıyız. İçimizden 'Hasta acaba bana bir şey mi söylemeye çalışıyor' diye geçirmek, umulmadık çıkarımlar sağlayabilir. Hastamızın moralini sorarak başlangıç yapabiliriz. Psikomotor ajitasyon ya da retardasyon var mı? Düşünce içeriği ve oryantasyonu ne durumda? Kişisel bakımı ne durumda? Saçları nasıl, kendi tarayabiliyor mu? Kıyafetleri nasıl, kendi başına giyinebiliyor mu? Yemek yemeyi ya da tuvalete gitmeyi kendi başına becerebiliyor mu? Proksimal kasların gücünü yansıtan merdiven çıkma ve oturup kalkma hareketlerini yapabiliyor mu? Distal kas gücünü yansıtan elin intrensek kaslarının yeteneği ne durumda, ayak parmak uçları üzerinde durabiliyor mu? Bu sorular bize kas gücünü ölçme ve mobilizasyon yeteneğini değerlendirme yanında depresyon açısından anlamlı olan günlük aktivitelere ilgi ve öz bakım hakkında da ipuçları sağlamış olacaktır. Depresyondaki his; yapılan etkinlikten tat alamama, etkinliğin zevk vermemesi şeklindedir. Temeldeki sorun hastanın kendisini beceriksiz ve işe yaramaz hissetmesidir. Yorgunlukta ise istek aslında korunmuştur. Egzersize verilen tepki de işimize yarayabilir. Depresyon hastaları egzersiz yapabilirse hem yorgunluğun azaldığını hem de geçici de olsa karamsarlık hislerinin azaldığını fark ederler. Yorgunluk hastalarında ise programsız ya da zorlayarak yaptırılan egzersiz yakınmaların daha da şiddetlenmesine neden olacaktır. Ayrıca, hastamızın uyku kalitesi üzerinde durulmalıdır. Bunu yaparken muhakkak aklımızın bir köşesinde, toplumdaki sıklığı kabaca \%2 olan ve süregelen aralıklı hipoksi ataklarının yorgunluğa yol açtığı düşünülen uyku apne sendromu bulunmalıdır. Hastanın birlikte yaşadığı yakını geceleri horlama ve nefes durması yani apne atağına şahitlik açısından, kendisi de sabahları yorgun uyanma ve gün içinde uyuklama açısından sorgulanmalıdır. Fizik muayene muhtemelen belirgin bir katkı sağlamayacaktır ancak şikayetlerin ciddiye alındığını hissettirmesi ve hastanın güven duygusunu pekiştirmesi açısından önem taşımaktadır. Hasta odaya girdiği aşamada endokrin hastalıklar için uyarıcı niteliğinde olabilen genel görünümü açısından süzülmelidir. Ardından genel durumu nasıl sorusunu kendimize sormalıyız. Resim 2'de muayene esnasında dikkat edilmesi gereken yerler detaylıca gösterilmiştir.

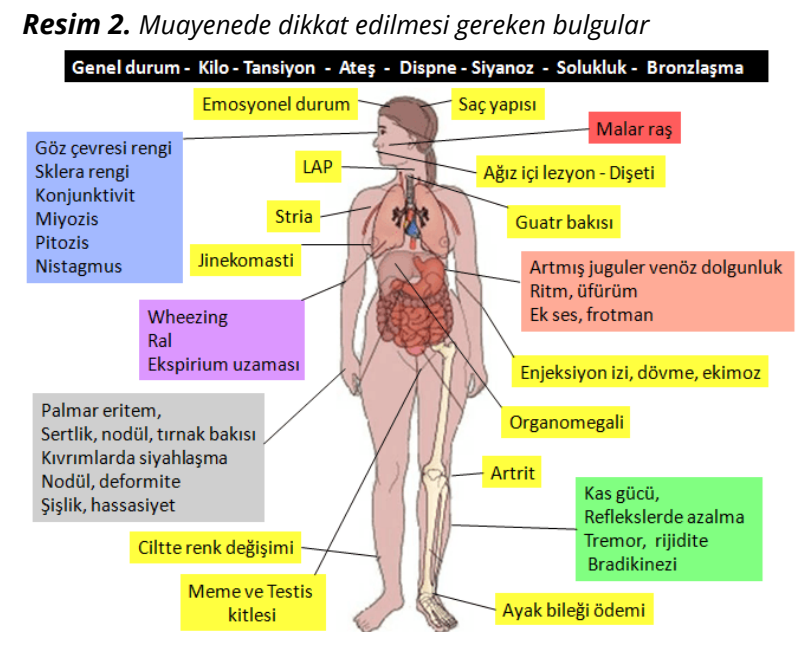

Anamnez ve fizik muayenede belirgin bulgu yakalanamazsa, maalesef tahlillerin anlamsız minör değişiklikleri saptamak dışında pek katkı sağlayamayacağı görülecektir. Yapılan çalışmalarda laboratuvar analizlerinin kabaca \%5-10 oranında anormallik saptayabildiği, kronik yorgunluk durumunda ise ancak \%8 oranında tanıyı değiştirebilecek katkı sunduğu anlaşılmıştır. Pratik hayatta laboratuvar analizleri sonrasında nedenin açıklanamadığı haller hekimleri zorlayabilmektedir. Ayrıca; tatminsiz hasta grubunun sık poliklinik başvurusu, istenilen birçok tetkik ve özgül olmayan ilaç tedavileri de işgücü ve ekonomik kayıpları beraberinde getirmektedir. Bu yüzden ilk başvuru testleri normal olarak saptanmış ise genellikle testlerin tekrarlanmaması önerilir. Böyle bir durumda başka bir hekim gözüyle ya da psikiyatrik değerlendirmenin daha çok işe yarayacağı belirtilmektedir. 2004-2006 yılları arasında kronik yorgunluktan muztarip Hollandalı vatandaşlar 
arasında 570 kişi ile yapılan bir izlem çalışmasında; takipte hastaların \%10'unda tam kür sağladığı, \%20-60'ının iyileştiği ancak \%10-20'lik bir kesimin kötüleştiği görülmüştür (26). Prognozda ileri yaş, uzun hastalık süresi, semptomlardaki yoğunluk ve eş zamanlı psikiyatrik bozukluk varlığı kötü yönde etkiler oluşturmaktadır (27). Adölesanlarda yorgunluğun prognozu ise genel olarak daha iyi kabul edilir.

\section{Tedavi:}

Araştırma sonucunda altta yatan bir hastalık bulunursa öncelikle bu durum giderilmelidir. Mevcut nedenler ortadan kaldırılamıyorsa yorgunluk semptomu genelde kronikleşir ve tedavisi güçleşir. Böyle bir durumda amaç hastanın günlük aktivitelerini sürdürmesini ve insanlar ile olan ilişkilerinin devamını sağlamak yönünde olmalıdır. Kişiye depresyon tanısı konmuş ise fluoksetin, paroksetin, sertralin gibi antidepresanlar ile tedavinin en azından 6 hafta süreyle uygulanması; uykusuzluk problemi ön planda ise trazodon veya ağrı semptomu ön planda ise venlafaksin ya da duloksetin seçimine ağırlık verilmesi önerilmektedir. Henüz anemi gelişmemiş dahi olsa düşük ferritin düzeyi halsizliğe yol açabilmektedir. Bu konuda demir replasmanının ancak dördüncü haftada enerji hissinde artış sağlayacağı bilinmelidir. Ayrıca malignite, kronik böbrek yetmezliği ve diğer kronik hastalıklara bağlı anemide gereğinde eritropoetin tedavisi de devreye sokularak hemoglobin değerinin $10 \mathrm{mg} / \mathrm{dl}$ civarı tutulmaya çalışılması hastaların daha az yorgunluk hissinden yakınmasını sağlamaktadır. Dopaminerjik ajan olan metilfenidat, dekstroamfetamin ve modafinil gibi psikostimülanlar malignite, multipl skleroz ya da HIV pozitif hastalarda kısa süreli olarak denenebilir. Terminal dönem hastalıkta ayrıca steroid de kullanılabilir. Ancak yapılan bir çalışmada metilfenidat ile beklenen etki sağlanamadığı yayınlanmıştır (28). Modafinil de mekanizması tam bilinmeyen normalde narkolepside onaylı bir ilaçtır. Kalp hastalığı ve kontrolsüz hipertansiyonu olan hastalarda dikkatli kullanılması öğütlenir. Ayrıca anksiyete ve depresyon şikayetlerini kötüleştirebileceği de bilinmelidir.

İdiyopatik kronik yorgunluk söz konusu olduğunda tedavi aşamasında diğer aile bireylerinin de görüşmeye davet edilebileceği hasta hekim ilişkisinin önemi hemen göze çarpar. Nitekim kronik yorgunluk sendromlu hastalar kognitif davranışsal terapiye cevap verebilmektedir. Bu kişilerde öncelikle halsizlik nedeni olabilecek ilaçlar kesilerek işe başlanır. Örneğin, sedatize etmediği söylenen antihistaminiklerde dahi \%8-15 oranında sedasyon izlenebilir. Ardından fizyolojik ihtiyaçları düzenlemeliyiz. Bu doğrultuda uyku, diyet, sosyal aktivite, iş yaşamı ve stres hali değerlendirilmelidir. Kronik yorgunluk hisseden kişi işe devam etme yönünde cesaretlendirilmelidir. Operasyon geçirmiş olsa dahi post-op yorgunluğun en fazla 3 ay süreceği bilinmeli ve sonrasında işe dönüş teşvik edilmelidir. Çalışma saatlerinde aşırıya kaçmaktan sakınılmalıdır. Sürekli stres yaratan faktörler ortadan kaldırılmalı ayrıca bedeni ve zihni rahatlatacak yollar öğütlenmelidir. Ancak; bir kısım hastada iş tükenmişliği gelişmiş olma intimali de göz önünde bulundurularak, gerekli görülürse izin kullandırılmalıdır. Saat 13:00 ve 15:00 sularında en fazla bir saat süreyle yapılacak bir şekerleme kimi hastalarda yardımcı olabilir. Normal bir yetişkinin vücudu için ideal uyku 7-8 saat sürmelidir. İyi bir uyku hijyeni için: mümkünse sabahları uyanma vakti aynı saatte olmalı, ağır aktiviteler öğleden sonra yapılmalı, uykudan önce ya da akşam vakti egzersizden kaçınılmalı, gündüzleri güneşle temas arttırılmalıdır. Akşam saatlerinde fazla yemek, içecek, kafein, nikotin ve alkol tüketiminden kaçınılmalıdır. Yatmadan 2 saat önce alınan sıcak duş iyi bir etki sağlayacaktır. Yatak odasında televizyon bulundurulmamalı, bu oda sadece uyku amaçlı şartlandırılmalıdır. Ayrıca uykuya dalma esnasında ortamın gürültüsüz, karanlık ya da loş olması sağlanmalıdır. Melatoninin kullanımı etkisi net olarak kanıtlanmasa da uyku probleminde düşünülebilir. Kronik halsizlik ve yorgunlukta istirahatten ziyade ılımlı ve düzenli aerobik aktiviteler önerilmektedir. Faydalı olduğu gösterilmiş hiçbir spesifik diyet yoktur, ancak dengeli beslenme ve yeterli sıvı tüketimi önerilmelidir. Bol yağlı, tuzlu ve şekerli hazır gıdalardan uzak durulmalıdır. Özellikle aç karnına çok fazla karbonhidrat içeren besinlerin tüketilmesinden kaçınılmalıdır.

Kronik yorgunluk semptomunda B vitamini, CoQ10 ve koenzim kompleksleri mitokondriyal disfonksiyon, inflamasyon ve oksidatif stres basamaklarına faydalı etkileri olabildiği düşüncesiyle sık kullanılmaktadır (29). PPARy'nın doğal ligandı olan polianstüre omega 3 yağ asitlerinin de IL6 düzeyi ve inflamasyonu azaltabildiği gözlenmiştir. Bu etkilerin transkripsiyon faktörleri ve gen ekspresyonunu düzenleyerek oksidatif stresle alakalı NF-k $\beta$ aktivasyonunun inhibe edilmesiyle sağlandığı düşünülmektedir. Levokarnitin 
suplementasyonunun mitokondriyal yağ asidi oksidasyonu artışı ile özellikle renal yetmezlik, malignite ve kronik hepatit tablolarında yorgunluğu azaltarak yaşam kalitesini arttırdığı saptanmıştır (30).

Bitkisel destek ürünler günümüzde hastalar arasında oldukça popüler hale gelmiştir. Bunların kullanımı esnasında bireyselleştirilmiş doz ayarına; kalp, karaciğer ve böbrek fonksiyonlarındaki değişime, yan etkilere ve özellikle antidepresan ve antikoagülanlar başta olmak üzere ilaç etkileşimlerine dikkat edilmelidir. Bu ürünlere kısaca değinecek olursak: Yeşil çayda bulunan epigallocatechin gallate TNF alfa ve IL-6 seviyelerini azaltarak antiinflamatuvar etki sergilemektedir. Quercetin bir çeşit flavonoid olup en çok üzüm, kiraz, karadut, elma kabuğu, soğan, şarap ve balda bulunur. Doğal bir antioksidandır ve mast hücrelerinin degranülasyonunu inhibe etmektedir. Rüşeym yağı buğday tanesinin filizlenme için gerekli tüm enerji ve besin kaynaklarını barındıran embriyo kısmıdır. Yapısında esansiyel yağ asitleri, oktakosonol ve polikosanol, A, D ve E vitaminini bulundurur. Yaşlanma etkilerini geciktirdiği, bağışıklık sistemini desteklediği ve yorgunluk giderici etkisi olduğu söylenmektedir. Kreatin ise enerji metabolizmasında görevli bir aminoasit türevi olup vücudumuzdaki miktarının \%95'i kaslarda depolanmaktadır. Diyet yoluyla vücuda sağlanan ve ince bağırsaktan kolaylıkla emilebilen bu madde en yoğun kırmızı et ve balıkta bulunur. Az miktarda da karaciğer, böbrek ve pankreasta arginine, glycine ve methionineden sentezlenir. Kreatin alındıktan sonra geç etki göstermekte ve sıklıkla sporcular arasında kas gücü ve kitlesini arttırmak adına tercih edilmektedir. Yapılan çalışmalarda düşük doz kullanımının yorgunluğa iyi geldiği yönünde yayınlar mevcuttur (31). Geleneksel Çin tıbbının kadim ilacı konumundaki ginseng yorgunlukta adaptogen ve stresi azaltma etkileriyle kurutulmuş kökleri toz haline getirilerek kapsül şeklinde kullanılmaktadır (32). Yine Güney Amerika kıtasındaki And dağlarında yetişen Maca, Asya ve Avrupa'nın kutupsal dağlık yörelerinde bulunabilen rhodiola ve Güneydoğu Asya'ya has afrodizyak bir bitki türü olan Tongkat Ali (eurycoma longifolia) herbal tedavide adı geçen diğer ürünlerdir (33). Royal jelly, aslında arı sütü diye de bilinen ve işçi arıların tükürüğünden sentezlenen besin değeri yüksek bir üründür. Yapısında A, D, C, E ve B grubu vitaminler, aminoasitler, önemli mineraller, biyoaktif maddeler, panteik asit, bağışıklık sistemini güçlendiren dekanoik asit ve oleik asit bulunmaktadır. Antioksidan, immünomodülatör ve antiinflamatuvar etkileri olduğu kabul edilmektedir (34). Son olarak alglerden oluşan mikroskobik bir yosun türü olan spirulina adlı üründen bahsedebiliriz. Bu canlıda yüksek miktarda gamma-linolenik asit, poliansatüre yağ asitleri, ayrıca vitamin, beta karoten, çeşitli pigment ve mineralleri bulunur. HIV ve herpes başta olmak üzere virüslere karşı sitokin ve antikor üretimini arttırıp direnç sağlanmasında etkilidir ve yorgunlukta bazı ekoller tarafından önerilmektedir (35).

\section{Yazarlar arasında çıkar çatışması yoktur. \\ The author declares no conflict of interest. \\ Finansal Destek: yoktur / Funding : none \\ doi: https://doi.org/10.33713/egetbd.568526}

\section{KAYNAKLAR}

1. Sayın A, Candansayar S. Yorgunluk kavramı ve yorgun hastalara klinik yaklaşım, Gazi Tıp Dergisi 2007; Cilt 18: Sayı 1: 18

2. Cornuz J, Guessous I, Favrat B. Fatigue: a practical approach to diagnosis in primary care, CMAJ 2006; March 14,174(6)

3. Murtagh J. Fatigue - a general diagnostic approach, Australian Family Physician 2003; Vol. 32, No. 11, November

4. Stadje R. The differential diagnosis of tiredness: a systematic review, BMC Family Practice 2016; 17:147

5. Watanabe $N$, Stewart R, Jenkins $R$, Bhugrab DK, Furukawaa TA. The epidemiology of chronic fatigue, physical illness, and symptoms of common mental disorders: A cross-sectional survey from the second British National Survey of Psychiatric Morbidity. Journal of Psychosomatic Research 2008; 64, 357-362

6. Norheim KB, Jonsson G, Omdal R. Biological mechanisms of chronic fatigue, Rheumatology 2011; 50:1009-1018

7. Smith WR. Mortality in a cohort of chronically fatigued patients,Psychol Med. 2006; Sep, 36(9):1301-6

8. Louati K, Berenbaum F. Fatigue in chronic inflammation - a link to pain pathways, Arthritis Research \& Therapy 2015; $17: 254$

9. McCusker RH， Kelley KW. Immune-neural connections: how the immune system's response to infectious agents influences behavior, The Journal of Experimental Biology 2013; 216, 84-98

10. Morris et al., Central pathways causing fatigue in neuroinflammatory and autoimmune illnesses, BMC Medicine $2015 ; 13: 28$

11. Tanaka M, Tajima $S$, Mizuno $K$, Ishii $A$, Konishi $Y$, Miike $T$, Watanabe $Y$. Frontier studies on fatigue, autonomic nerve dysfunction, and sleep-rhythm disorder, J Physiol Sci 2015; 65:483-498

12. Gorniak BG, Puszczewicz M. Fatigue and interleukin-6 - a 
multi-faceted relationship, Reumatologia 2015; 53, 4: 207-212

13. Lasselin J, Capuron L. Chronic Low-Grade Inflammation in Metabolic Disorders: Relevance for Behavioral Symptoms, Neuroimmunomodulation 2014; 21:95-101

14. Chrousos GP. The Hypothalamic-Pituitary-Adrenal axis and immune-mediated inflamation, Seminars in medicine of the Beth Israel Hospital 1995; Boston, Vol. 332 No.20

15. Karshikoff B, Sundelin T, Lasselin J. Role of inflammation in Human Fatigue: Relevance of Multidimensional Assessments and Potential Neuronal Mechanisms, Frontiers in Immunology 2017; Volume 8, Article 21

16. Holmes GP. Chronic Fatigue Syndrome: A Working Case Definition, Ann Intern Med 1988; 108:387-389

17. Fukuda K. The Chronic Fatigue Syndrome: A Comprehensive Approach to Its Definition and Study, Ann Intern Med 1994; 121:953-959

18. Viner R, Christie D. Fatigue and somatic symptoms, BMJ 2005; Volume 330, 30 April

19. Rosenthal TC, Majeroni BA, Pretorius R, Malik K. Fatigue: An Overview, American Family Physician 2008; Volume 78, Number 10 , November 15

20. Friedman HH. Semptoma Yönelik Tanı Elkitabı. 7. Baskı. Turkiye : Nobel Tıp Kitabevi Inc 2004

21. Imboden JB, Hellmann DB, Stone JH. Current Diagnosis and Treatment Serisi Romatoloji Tanı ve Tedavi. 3. Baskı. Turkiye : Gunes Tıp Kitabevi Inc 2014

22. Smith BW, McCarthy JC, Dawley CA. Suspect myopathy? Take this approach to the work-up, The Journal of Family Practice 2014; Vol 63, No 11

23. Keser G. Miyopatik hastaya yaklaşım. Ege Ünversitesi Romatoloji Bölümü, Romatolojide yaklaşımlar ve yuvarlak masa toplantıları, Antalya 2016

24. Saguil A. Evaluation of the Patient with Muscle Weakness, American Family Physician 2005; April, Volume 71, Number 7

25. Şahin A., Cumhuriyet Üniversitesi Romatoloji Bölümü, Sayarlıoğlu M, 6. Romatoloji Vaka Derlemeleri, Türkiye Romatoloji Derneği 2016

26. Nijrolder I, Van der Windt $D$, Vries $H$, Van der Hors $H$. Diagnoses during follow-up of patients presenting with fatigue in primary care, CMAJ 2009; November 181(10)

27. Kılıçarslan A. Kronik Yorgunluk Sendromu, iç Hastalıkları Dergisi 2007; 14(2): 91-97

28. Moraska AR, Sood A, Dakhil SR, Sloan JA, Barton D, Atherton $\mathrm{PJ}$, et al. Phase III, randomized, doubleblind, placebo-controlled study of long-acting methylphenidate for cancer-related fatigue. North Central Cancer Treatment Group NCCTG-N05C7 trial. J ClinOncol; 28:3673, 2010

29. Marrero C, Does. Oral Coenzyme Q10 Plus NADH Supplementation Improve Fatigue and Biochemical Parameters in Chronic Fatigue Syndrome? Antioxidants \& Redox signaling 2015; Volume 22, Number 8

30. Vermeulen RCW, Scholte HR. Exploratory Open Label,
Randomized Study of Acetyl- and Propionylcarnitine in Chronic Fatigue Syndrome, Psychosomatic Medicine2004; 66:276-282

31. Rawson ES. Low-dose creatine supplementation enhances fatigue resistance in the absenceof weight gain 451-455, Nutrition 2011, 27

32. Barton DL. Pilot study of Panax quinquefolius (American ginseng) to improve cancer-related fatigue: a randomized, double-blind, dose-finding evaluation, Support Care Cancer 2010; 18(2): 179-187

33. Talbott SM., Effect of Tongkat Ali on stress hormones andpsychological mood state in moderately stressed subjects, Journal of the International Society of Sports Nutrition 2013; 10:28

34. Mofid B. Effect of Processed Honey and Royal Jelly on Cancer-Related Fatigue: A Double-Blind Randomized Clinical Trial, Electronic physician 2016; Volume: 8, Issue: 6, Pages: 2475-2482

35. Johnson M, Hassinger L, Davis J, Devor ST, DiSilvestro RA. A randomized, double blind, placebo controlled study of spirulina supplementation on indices of mental and physical fatigue in men, International Journal of Food Sciences and Nutrition 2016; Vol. 67, No. 2, 203-206 